\title{
Bacterial infections complicating tongue piercing
}

\author{
Catherine HY Yu MD FRCPC ${ }^{1,2}$, Brian J Minnema MD², Wayne L Gold MD FRCPC $2,3,4$
}

\begin{abstract}
CHY Yu, BJ Minnema, WL Gold. Bacterial infections complicating tongue piercing. Can J Infect Dis Med Microbiol 2010;21(1):e70-e74.
\end{abstract}

Tongue piercing has become an increasingly popular form of body art. However, this procedure can occasionally be complicated by serious bacterial infections. The present article reports a case of prosthetic valve endocarditis caused by a Gemella species in a patient with a pierced tongue, and reviews 18 additional cases of local and systemic bacterial infections associated with tongue piercing. Infections localized to the oral cavity and head and neck region included molar abscess, glossal abscess, glossitis, submandibular lymphadenitis, submandibular sialadenitis, Ludwig's angina and cephalic tetanus. Infections distal to the piercing site included eight cases of infective endocarditis, one case of chorioamnionitis and one case of cerebellar abscess. Oropharyngeal flora were isolated from all cases. While bacterial infections following tongue piercing are rare, there are reports of potentially life-threatening infections associated with the procedure. Both piercers and their clients should be aware of these potential complications, and standardized infection prevention and control practices should be adopted by piercers to reduce the risk.

Key Words: Bacterial infection; Body piercing; Endocarditis; Tongue piercing

Gor many years, body piercing at sites other than the earlobe has been a common practice in many cultures. The ancient Mayans pierced their tongues for spiritual purposes, while the Pharaohs of Egypt ceremoniously pierced their navels (1). While populationbased statistics are not available, it is apparent that ear and body piercing are becoming increasingly popular in the western world. With increasing levels of social acceptance, body art, including tongue piercing, has moved into mainstream culture and coincidentally with its gain in popularity, there have been reports of its attendant risks. Viral infections including hepatitis B, C and D (1), oral and dental trauma (2), and bleeding (3) have been reported and are recognized complications of tongue piercing. Although no cases have been reported in the literature, it is possible that HIV transmission could occur through body piercing as well. Furthermore, there is an emerging literature of cases of both local and systemic bacterial infections for which tongue piercing may be a causal factor (3-19)

We report a case of infective endocarditis that occurred in a man with surgically corrected congenital cyanotic heart disease and a pierced tongue. We also review the medical literature regarding bacterial infections associated with tongue piercing, and discuss pathogenesis, relevant infection control practices, and prevention strategies.

\section{METHODS}

Cases of bacterial infections associated with tongue piercing were identified through a MEDLINE search of articles published from January 1966 to February 2009. The key words and $\mathrm{MeSH}$ headings "tongue", "piercing", "tongue piercing", "punctures" and

\author{
Infections bactériennes compliquant le perçage \\ de la langue
}

Le perçage de la langue est une forme d'art corporel de plus en plus populaire. Toutefois, cette pratique peut, à l'occasion, se compliquer de graves infections bactériennes. Le présent article fait état d'un cas d'endocardite sur prothèse valvulaire causée par le genre Gemella chez un patient porteur d'un perçage à la langue et passe en revue 18 autres cas d'infections bactériennes localisées et systémiques associées à cette pratique. Les infections localisées à la cavité orale et à la région de la tête et du cou comprenaient l'abcès des molaires, l'abcès lingual, la glossite, la lymphadénite sous-mandibulaire, la sialadénite sous-mandibulaire, l'angine de Ludwig et le tétanos céphalique. Les infections éloignée du site du perçage ont inclut huit cas d'endocardite infectieuse, un cas de chorioamnionite et un cas d'abcès cérébelleux. La flore oropharyngée a été isolée dans tous les cas. Même si les infections bactériennes consécutives au perçage de la langue sont rares, des cas gravissimes ont été associés à cette pratique. Les personnes qui font des perçages et leurs clients doivent être au courant de ces complications potentielles et les personnes qui font des perçages doivent adopter des pratiques de prévention et de contrôle des infections pour réduire ce risque. 
TABLE 1

Bacterial infections, excluding cases of infective endocarditis, associated with tongue piercing

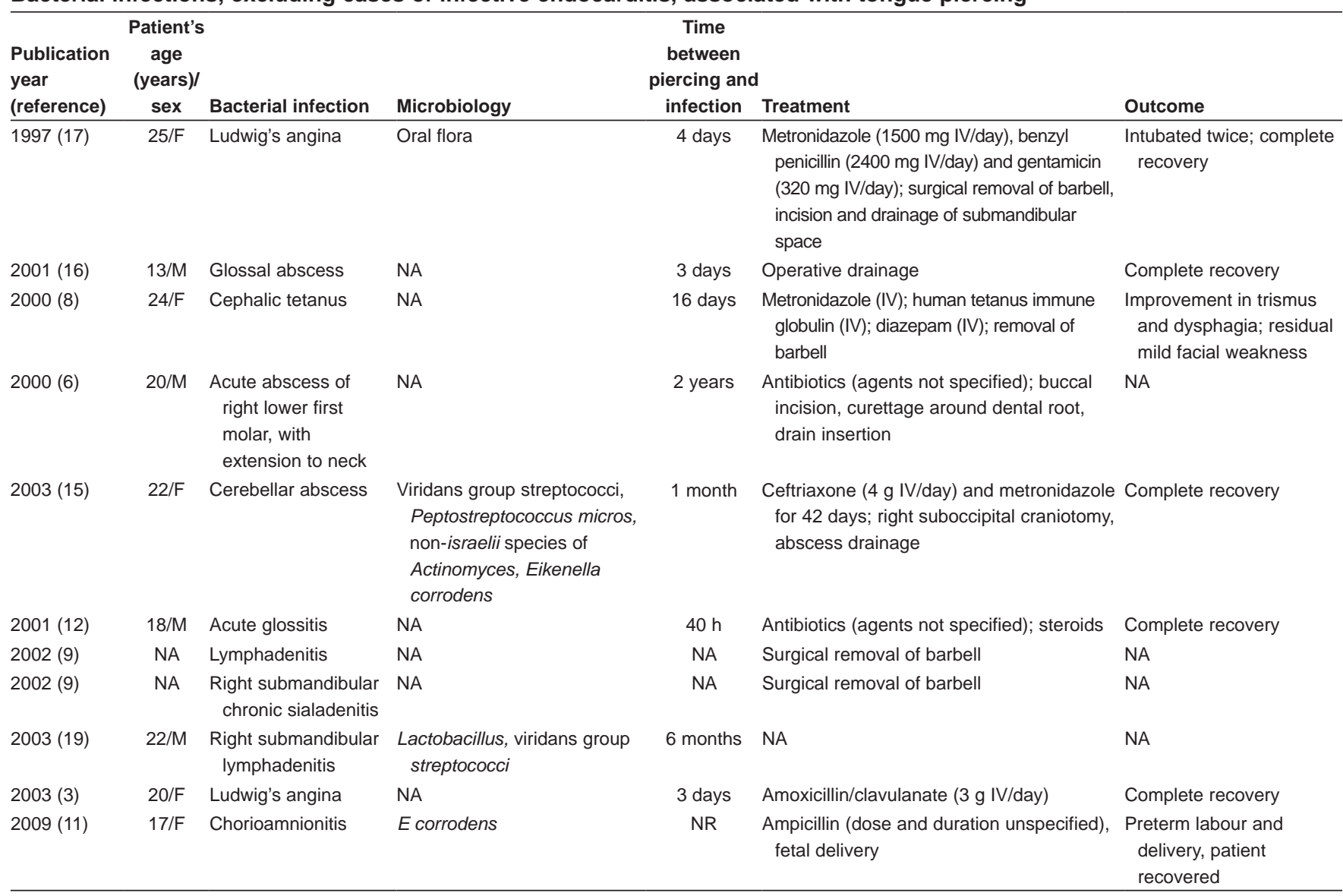

F Female; IV Intravenous; M Male; NA Not available; NR Not reported

before the onset of his symptoms, he had undergone tongue piercing and forearm tattooing, and six years before the onset of his symptoms, he had undergone nasal septum piercing. He removed the barbells in his tongue three or four times each year; the last time they were removed was before his recent dental visit. He denied flicking of the barbells against his teeth, although he bit the barbells occasionally. He was unaware of any gingival recession or chipped teeth related to the piercing, but did not consent to a review of his dental records.

On examination, his temperature was $39.3^{\circ} \mathrm{C}$. Head and neck examination revealed two laterally placed barbells piercing the tongue and a circular perforation of the nasal septum from his previous nasal piercing. Cardiovascular examination revealed a grade III/VI systolic ejection murmur and a grade III/VI early diastolic decrescendo murmur along the left and right sternal borders, respectively; both had been previously documented. There were no peripheral stigmata of infective endocarditis. There were tattoos on the forearms bilaterally.

A complete blood cell count revealed normocytic anemia; his white blood cell count was $4.1 \times 10^{9} / \mathrm{L}$ (granulocyte count was $3.2 \times 10^{9} / \mathrm{L}$ ) and his platelet count was $131 \times 10^{9} / \mathrm{L}$. Four of six blood culture bottles grew Gemella species. A transthoracic echocardiogram revealed a $2 \mathrm{~mm} \times 5 \mathrm{~mm}$ linear structure attached to the bioprosthetic pulmonary valve with turbulent flow in the left ventricle-to-pulmonary artery conduit. These features were not present on an echocardiogram performed eight months earlier.
A diagnosis of prosthetic valve endocarditis was made and treatment was initiated with a six-week course of intravenous penicillin $\mathrm{G} 3 \times 10^{6}$ units administered every $6 \mathrm{~h}$, and a two-week course of intravenous gentamicin $60 \mathrm{mg}$ administered every $12 \mathrm{~h}$. The patient made a full recovery without need for surgical intervention.

\section{RESULTS}

A review of the literature published from 1966 to 2009 identified 18 previously reported cases of bacterial infections occurring as complications of tongue piercing, including seven previously reported cases of infective endocarditis. The clinical features and outcomes of these cases, as well as the case in the present report, are summarized in Tables 1 and 2 . There were eight men and nine women; the sex was not specified in two of the cases. The average age of the patients for whom an age was recorded was 21.9 years (range 13 to 30 years).

Spectrum of bacterial infections: There were 19 infections, including the present case. Nine infections were localized to the oral cavity or head and neck regions. There were eight cases of infective endocarditis, including the case in the present report. There was one case of cerebellar abscess (15); the other case was of chorioamnionitis (11). The nine cases of infection that were localized to the oral cavity and head and neck region included glossitis (12), submandibular lymphadenitis $(9,19)$, submandibular sialadenitis (9), molar abscess (6), glossal abscess (16), Ludwig's angina $(3,17)$ and cephalic tetanus $(8)$. 
TABLE 2

Cases of infective endocarditis following tongue piercing

\begin{tabular}{|c|c|c|c|c|c|c|}
\hline $\begin{array}{l}\text { Publication } \\
\text { year } \\
\text { (reference) }\end{array}$ & $\begin{array}{l}\text { Patient } \\
\text { age } \\
\text { (years)/ } \\
\text { sex }\end{array}$ & Microbiology & $\begin{array}{c}\text { Time } \\
\text { between } \\
\text { piercing } \\
\text { and } \\
\text { infection }\end{array}$ & $\begin{array}{l}\text { Pre-existing } \\
\text { valvular heart } \\
\text { disease }\end{array}$ & Treatment & Outcome \\
\hline 2001 (18) & $20 / F$ & Neisseria mucosa & 1 month & NA & $\begin{array}{l}\text { Ceftriaxone ( } 2 \text { g IV/day) and } \\
\text { ciprofloxacin ( } 400 \mathrm{mg} \text { IV/day) for } \\
28 \text { days }\end{array}$ & $\begin{array}{l}\text { Twofold reduction in vegetation size, } \\
\text { stable MR; complete recovery }\end{array}$ \\
\hline 2002 (4) & $25 / \mathrm{M}$ & $\begin{array}{l}\text { Haemophilus } \\
\text { aphrophilus }\end{array}$ & 2 months & $\begin{array}{l}\text { Surgically corrected } \\
\text { congenital aortic } \\
\text { stenosis }\end{array}$ & $\begin{array}{l}\text { Ceftriaxone (IV) and gentamicin (IV) } \\
\text { for } 42 \text { days }\end{array}$ & Lost to follow-up \\
\hline 2002 (10) & $18 / F$ & $\begin{array}{l}\text { Methicillin-resistant } \\
\text { Staphylococcus } \\
\text { aureus }\end{array}$ & 1 week & None & $\begin{array}{l}\text { Antibiotics (unspecified) and mitral } \\
\text { valve replacement }\end{array}$ & $\begin{array}{l}\text { CT and MRI findings consistent with } \\
\text { embolization to brain before surgical } \\
\text { repair; clinical outcome not specified }\end{array}$ \\
\hline $2004(7)$ & $18 / F$ & S aureus & 6 weeks & None & $\begin{array}{l}\text { Vancomycin (IV) for } 42 \text { days followed by } \\
\text { mitral valve replacement }\end{array}$ & $\begin{array}{l}\text { Continued embolic complications } \\
\text { following course of antibiotics; } \\
\text { proceeded to mitral valve replacement }\end{array}$ \\
\hline $2004(5)$ & $25 / M$ & $\begin{array}{l}\text { Streptococcus } \\
\text { constellatus }\end{array}$ & 2 years & None & $\begin{array}{l}\text { IV antibiotics (unspecified) followed by } \\
\text { aortic valve replacement }\end{array}$ & \\
\hline 2005 (14) & $27 / M$ & $\begin{array}{l}\text { Viridans group } \\
\text { streptococci }\end{array}$ & 6 weeks & $\begin{array}{l}\text { Bicuspid aortic } \\
\text { valve }\end{array}$ & $\begin{array}{l}\text { Penicillin G }\left(18 \times 10^{6} \mathrm{U} / \text { day and }\right. \\
\text { gentamicin }(240 \mathrm{mg} / \text { day }) \text { for } 42 \text { days; } \\
\text { Ross procedure for abscess }\end{array}$ & Complete recovery \\
\hline 2007 (13) & $30 / F$ & $\begin{array}{l}\text { Alpha hemolytic } \\
\text { Streptococcus }\end{array}$ & NR & None & $\begin{array}{l}\text { IV antibiotics (unspecified) and mitral } \\
\text { valve replacement }\end{array}$ & Complete recovery \\
\hline 2009 (present) & 29/M & Gemella species & 3 years & $\begin{array}{l}\text { Surgically corrected } \\
\text { transposition of the } \\
\text { great arteries }\end{array}$ & $\begin{array}{l}\text { Penicillin G }\left(12 \times 10^{6} \mathrm{U} \text { IV/day) for }\right. \\
42 \text { days and gentamicin }(120 \mathrm{mg} \\
\text { IV/day) for } 14 \text { days }\end{array}$ & Complete recovery \\
\hline
\end{tabular}

CT Computed tomography; F Female; IV Intravenous; M Male; MR Mitral regurgitation; MRI Magnetic resonance imaging; NA Not available; NR Not reported

Predisposing factors to infection: Three of the eight cases of infective endocarditis were documented to have predisposing valvular heart disease $(4,14)$.

Time from piercing to the onset of infection: The time between the tongue piercing and the onset of symptoms was recorded for 15 of the 19 cases, including seven of the eight cases of infective endocarditis. The median time was 30 days (range $40 \mathrm{~h}$ to three years). For the cases of endocarditis, the median time to infection following tongue piercing was six weeks (range one week to three years).

Piercing setting/piercer: There were limited data regarding the setting in which the piercings were performed. All procedures were performed by nonmedical and nondental practitioners in cases for which this information was recorded. One piercing was performed by the patient himself (16), and another involved a patient allowing a friend to use her tongue stud to pierce him (10).

Use of prophylactic antibiotics: Prophylactic antibiotics were not administered to any of the patients before the procedures.

Microbiology: Microbiological data were available in 11 cases. Microorganisms responsible for the infections included viridans group streptococci, Peptostreptococcus micros, a non-israelii species of Actinomyces, Eikenella corrodens, a Lactobacillus species, Neisseria mucosa, Haemophilus aphrophilus and Staphylococcus aureus, including one case involving a methicillin-resistant $S$ aureus (MRSA) strain.

Treatments and outcomes: Details regarding treatment were recorded for 18 of the 19 cases. Five patients were treated with antibiotics alone, three patients were treated with surgery alone, and the remaining patients were treated with a combination of medical and surgical therapies. In one case, the management was not recorded. Surgical procedures included surgical removal of the barbell $(8,9,17)$, incision and drainage of a glossal abscess (16), incision and drainage of a molar abscess (6), surgical decompression of the floor of the mouth in the case of Ludwig's angina (17), craniotomy with drainage of a cerebellar abscess (15), fetal delivery (11), mitral valve replacement $(7,10)$, and a Ross reconstruction of the pulmonic and aortic valves (14). With the exception of mild facial weakness in the case of cephalic tetanus, all patients for whom outcomes were recorded experienced complete recovery.

\section{DISCUSSION}

Although piercing as a form of body art has become increasingly popular (20), precise statistics on the prevalence of tongue piercings as a subset of these procedures are not known. In a survey of college students, 47 of 454 (10.4\%) respondents reported having their tongues pierced (21). In a German registry of patients with head and neck piercings, 92 of 273 (33.7\%) patients reported having their tongues pierced (22). In a further survey (23) of children, adolescents and adults with congenital heart disease, $43 \%$ of respondents self-reported ear piercings, with no reports of intraoral piercings. Likewise, the rate of bacterial infections associated with tongue piercing is not known. While prevalence data are lacking, in a self-completed questionnaire study of individuals with intraoral piercings in San Francisco (USA), Boardman and Smith (2) found that three of 51 respondents with tongue piercings developed an infection and two of 51 respondents sought medical or dental attention for these infections. A similar survey (21) of undergraduate university students in the United States found that none of the 47 respondents with tongue piercings reported bacterial infections as a complication of the piercing. A survey (24) of tongue piercing recipients in the United Kingdom also resulted in no reports 
of bacterial infections among 122 respondents. The review of the literature reveals that while bacterial infections are apparently rare following tongue piercing, potentially serious bacterial infections can be a complication of this procedure and physicians should be aware of these complications.

The tongue piercing procedure involves perforation of the piercing site (usually in the midline of the tongue) with a 12 or 16-gauge needle following a brief cleansing of the oral cavity with a mouthwash. A longer barbell is initially placed to accommodate edema of the tongue that may develop. Following a three-to six-week healing period, it is replaced with a shorter, permanent barbell. Postoperative instructions include use of antibacterial mouthwash or salt water after each meal, use of a new toothbrush, and avoidance of smoking, alcohol, chewing gum, spicy, salty or acidic foods and oral sexual contact $(25,26)$. A more detailed description of this procedure can be found elsewhere $(25,27,28)$. Factors predisposing to the subsequent development of bacterial infection may be separated into those related to mucosal injury during the procedure with invasion of oral bacteria and possible transient bacteremia, those related to the infection control practices surrounding the piercing procedure, and those related to the ongoing trauma to the oral cavity resulting from the persistent presence of a foreign body in the tongue.

The oral cavity is a complex environment for microbes. Factors that influence the composition of the oral flora include age, diet and nutrition, oral hygiene practices, smoking, the presence of dental caries and periodontal disease, hospitalization and recent antimicrobial exposure (29-31). Organisms that have a predilection for colonizing the tongue and buccal mucosa include aerobic streptococci (such as viridans group streptococci, Gemella species and lactobacilli), anaerobic streptococci and anaerobic Gram-positive bacilli, such as Actinomyces species (32-34). These bacteria are represented among the organisms responsible for the infections included in the present report. In addition, there is one report (10) of infective endocarditis caused by MRSA following tongue piercing that we included in the review. Although MRSA is more typically associated with colonization of the nares, we have included this case because $S$ aureus may occasionally colonize the oral cavity and because the case was previously published as a case of infective endocarditis associated with tongue piercing. Furthermore, the temporal relationship between the piercing event and the subsequent development of infection in the case strongly implicates the piercing in its pathogenesis.

In addition to the role of oral microbes in the pathogenesis of bacterial infections complicating tongue piercing, the tongue has a rich vascular supply allowing for the development of transient bacteremias in the setting of mucosal injury. The initial penetrating trauma to the tongue is followed by a three- to six-week period of healing $(1,2)$ that may represent a period during which bacteria become bloodborne with the potential for hematogenous seeding of distant sites. Factors that increase inflammation, including metal allergic reactions and improper sizing and positioning of the barbell, may delay healing and promote infection $(26,35)$. In a survey of tongue piercing recipients in England (United Kingdom), noninfectious complications such as recurrent bleeding, swelling and pain were commonly reported for the first week after tongue piercing (24). Following the initial healing period, the presence of tongue jewellery presents an ongoing risk of traumatic injury to the teeth and periodontal tissues (35). The ongoing risk of transient bacteremias that may follow such dental or gingival trauma may predispose to the development of infections, such as the case of endocarditis described in the present report, at a time that is remote from the piercing. Finally, the failure to adhere to aseptic technique on the part of the piercer and postoperative care on the part of the client may further increase the risk of infection. The case of cephalic tetanus occurring 16 days following tongue piercing (8) supports the inoculation of Clostridium tetani at the time of the procedure.

Despite the serious and potentially preventable nature of the infectious complications of tongue piercing, the act of body piercing remains largely unregulated. This procedure is frequently performed by unlicensed persons in unregistered body art parlours with inconsistent use of patient screening tools, infection control protocols, or pre- and postprocedural counselling of the client. The American Dental Association, in recognition of the potentially serious sequelae of intraoral piercing, has issued a statement (36) opposing its practice and supports legislation that requires parental consent for minors. While many American states have introduced legislation regulating the act of tongue piercing, these laws are not standardized. Some states only require written parental consent for minors, while others mandate registration, licensing and reinforcement of infection control protocols by way of biannual on-site inspections. Canadian legislation requires parental consent for persons younger than 18 years of age and adherence to infection control protocols including needle disposal, autoclaving of reusable instruments, monthly spore testing and routine site inspections of registered studios. However, there are no laws prohibiting unregistered studios to practise (36). Regulations on practitioner training, patient screening, jewellery standards, and pre- and postprocedural counselling are also absent.

In a review of practices in Edmonton, Alberta, Botchway (37) observed variability in piercer training, patient screening procedures, as well as postprocedural counselling. Training periods for piercers ranged from one week to one year. Relevant medical history, including the presence of valvular heart disease, an immunocompromised state and the use of warfarin were not consistently included as part of patient screening. Discrepancies in postprocedural recommendations for mouthwash choice and infection management were also found. Similar findings were discovered in a more recent survey (24) of body art parlours in the United Kingdom. Based on these findings, recommendations have been made for standardization of patient screening, procedural training, and consultation with medical or dental professionals in cases of complications (38).

Finally, although there is no specific reference to tongue piercing as a bacteremia-producing procedure in the American Heart Association's recommendations for the prevention of bacterial endocarditis, prophylaxis is recommended for procedures involving the oral cavity in patients with high-risk and moderate-risk cardiac conditions predisposing to the development of infective endocarditis. Consequently, we recommend that patients with high-risk cardiac conditions who choose to undergo tongue piercing should consult their physicians or dentists and should strongly consider infective endocarditis prophylaxis before the procedure, as do other authors $(4,39)$. The recommended standard prophylactic regimen for dental procedures that involve perforation of the oral mucosa is a single dose of $2 \mathrm{~g}$ of oral amoxicillin $1 \mathrm{~h}$ before the procedure (34). 
The case presented occurred in a patient with a surgically constructed systemic pulmonary conduit. While endocarditis prophylaxis may have protected against the development of endocarditis at the time of the piercing, this infection occurred three years following the piercing procedure. In one other reviewed case (5), endocarditis occurred two years after tongue piercing. In cases such as these, that are remote from the piercing procedure, the degree to which tongue piercing is responsible for the development of endocarditis cannot be stated with certainty. However, the presence of oral jewellery has been shown to predispose to mucosal inflammation, gingival recession and dental injury (40). These factors likely translate to increased rates of transient bacteremia in patients with oral piercings, and highlights the ongoing risk of bacterial infection remote from the piercing procedure. We believe that cases of endocarditis and other infections remote from the piercing procedure highlight this risk of oral jewellery. We recommend that patients with cardiac conditions predisposing to endocarditis be counselled against tongue piercing, because the dental trauma related to oral jewellery represents an ongoing risk for the development of infective endocarditis.

The case report illustrates that bacterial infections associated with tongue piercing are an emerging complication of this increasingly popular form of body art. In some cases, these infections may be preventable. Health care professionals should obtain a history of tongue piercing in unexplained cases of infective endocarditis, brain abscess and intraoral infections for which piercing may be a risk. The report also highlights the unregulated nature of the body art profession as well as the urgent need for collaboration among dental, medical and body piercing professionals. Body art professionals should be educated on appropriate infection control and sterilization practices and should be subject to the same regulations required of health care professionals.

ACKNOWLEDGEMENTS: The authors have no financial support or conflicts of interest to declare.

\section{REFERENCES}

1. Tweeten SS, Rickman LS. Infectious complications of body piercing. Clin Infect Dis 1998;26:735-40.

2. Boardman R, Smith RA. Dental implications of oral piercing. J Calif Dent Assoc 1997;25:200-7.

3. Shacham R, Zaguri A, Librus HZ, Bar T, Eliav E, Nahlieli O. Tongue piercing and its adverse effects. Oral Surg Oral Med Oral Pathol Oral Radiol Endod 2003;95:274-6.

4. Akhondi H, Rahimi AR. Haemophilus aphrophilus endocarditis after tongue piercing. Emerg Infect Dis 2002;8:850-1.

5. Batiste C, Bansal RC, Razzouk AJ. Echocardiographic features of an unruptured mycotic aneurysm of the right aortic sinus of Valsalva. J Am Soc Echocardiogr 2004;17:474-7.

6. De Moor R, De Witte A, De Bruyne M. Tongue piercing and associated oral and dental complications. Endod Dent Trauma 2000;16:232-7.

7. Dubose J, Pratt JW. Victim of fashion: Endocarditis after oral piercing. Curr Surg 2004;61:474-7.

8. Dyce O, Bruno JR, Hong D, Silverstein K, Brown MJ, Mirza N. Tongue piercing. The new "rusty nail"? Head Neck 2000;22:728-32.

9. Folz BJ, Lippert BM, Kuelkens C, Werner JA. Jewelry-induced diseases of the head and neck. Ann Plast Surg 2002;49:264-71.

10. Harding PR, Yerkey MW, Deye G, Storey D. Methicillin resistant Staphylococcus aureus (MRSA) endocarditis secondary to tongue piercing. J Miss State Med Assoc 2002;43:109.

11. Jadhav AR, Belfort MA, Dildy GA III. Eikenella corrodens chorioamnionitis: Modes of infection? Am J Obstet Gynecol 2009;200:e4-5.

12. Keogh IJ, O’Leary G. Serious complication of tongue piercing. J Laryngol Otol 2001;115:233-4.

13. Kloppenburg G, Maessen JG. Streptococcus endocarditis after tongue piercing. J Heart Valve Dis 2007;16:328-30.

14. Lick SD, Edozie SN, Woodside KJ, Conti VR. Streptococcus viridans endocarditis from tongue piercing. J Emerg Med 2005;29:57-9.

15. Martinello RA, Cooney EL. Cerebellar brain abscess associated with tongue piercing. Clin Infect Dis 2003;36:e32-4.

16. Olsen JC. Lingual abscess secondary to body piercing. J Emerg Med 2001;20:409.

17. Perkins CS, Meisner J, Harrison JM. A complication of tongue piercing. Br Dent J 1997;182:147-8.

18. Tronel H, Chaudemanche H, Pechier N, Doutrelant L, Hoen B. Endocarditis due to Neisseria mucosa after tongue piercing. Clin Microbiol Infect 2001;7:275-6.

19. Zaharopoulos P. Fine-needle aspiration cytology in lesions related to ornamental body procedures (skin tattooing, intraoral piercing) and recreational use of drugs (intranasal route). Diagn Cytopathol 2003;28:258-63.

20. Stirn A. Body piercing: Medical consequences and psychological motivations. Lancet 2003;361:1205-15.

21. Mayers LB, Judelson DA, Moriarty BW, Rundell KW. Prevalence of body art (body piercing and tattooing) in university undergraduates and incidence of medical complications. Mayo Clin Proc 2002;77:29-34.

22. Krause H, Bremerich A, Sztraka M. [Complications following piercing in the oral and facial region]. Mund Kiefer Gesichtschir 2000;4:21-4.

23. Cetta F, Graham LC, Lichtenberg RC, Warnes CA. Piercing and tattooing in patients with congenital heart disease: Patient and physician perspectives. J Adolesc Health 1999;24:160-2.

24. Stead LR, Williams JV, Williams AC, Robinson CM. An investigation into the practice of tongue piercing in the South West of England. Br Dent J 2006;200:103-7; discussion 93.

25. Hardee PS, Mallya LR, Hutchison IL. Tongue piercing resulting in hypotensive collapse. Br Dent J 2000;188:657-8.

26. Piercers TAoP. The Association of Professional Piercers, 2008.

27. Fehrenbach MJ. Tongue piercing and potential oral complications. J Dent Hyg 1998;72:23-5.

28. Knox K. The potential complications of intra-oral and peri-oral piercing. Dental Health 2002;41:10-4.

29. Geddes D, Jenkins G. Intrinsic and extrinsic factors influencing the flora of the mouth. In: Skinner F, Carr J, eds. The Normal Microbial Flora of the Mouth. London: Academic, 1974:85.

30. Schuster G. The microbiology of oral and maxillofacial infections. In: Topazian RG, Goldberg MH, eds. Oral and maxillofacial infections, 2nd edn. Philadelphia: Saunders, 1987:33.

31. Yao ES, Lamont RJ, Leu SP, Weinberg A. Interbacterial binding among strains of pathogenic and commensal oral bacterial species. Oral Microbiol Immunol 1996;11:35-41.

32. Chow AW, Roser SM, Brady FA. Orofacial odontogenic infections. Ann Intern Med 1978;88:392-402.

33. Hamada S, Slade HD. Biology, immunology, and cariogenicity of Streptococcus mutans. Microbiol Rev 1980;44:331-84.

34. Hardie J. Microbial flora of the oral cavity. In: Schuster G, ed. Oral Microbiology and Infectious Disease, 2nd edn. Baltimore: Williams and Wilkins, 1962.

35. Campbell A, Moore A, Williams E, Stephens J, Tatakis DN. Tongue piercing: Impact of time and barbell stem length on lingual gingival recession and tooth chipping. J Periodontol 2002;73:289-97.

36. Infection Prevention and Control Practices for Personal Services: Tatooing, Ear/Body Piercing, and Electrolysis. Ottawa: Health Canada, 1999.

37. Botchway $\mathrm{C}$. The need for standardization of practice among tongue piercers. J Can Dent Assoc 2001;67:18-9.

38. Biber JT. Oral piercing: The hole story. Northwest Dent 2003;82:13-7,34.

39. Millar BC, Moore JE. Antibiotic prophylaxis, body piercing and infective endocarditis. J Antimicrob Chemother 2004;53:123-6.

40. Mathisen GE, Johnson JP. Brain abscess. Clin Infect Dis 1997;25:763-79; quiz 780-1. 


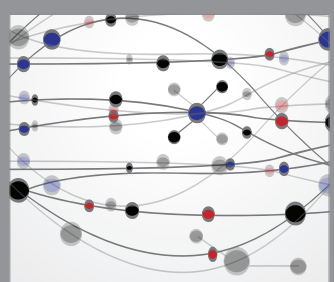

The Scientific World Journal
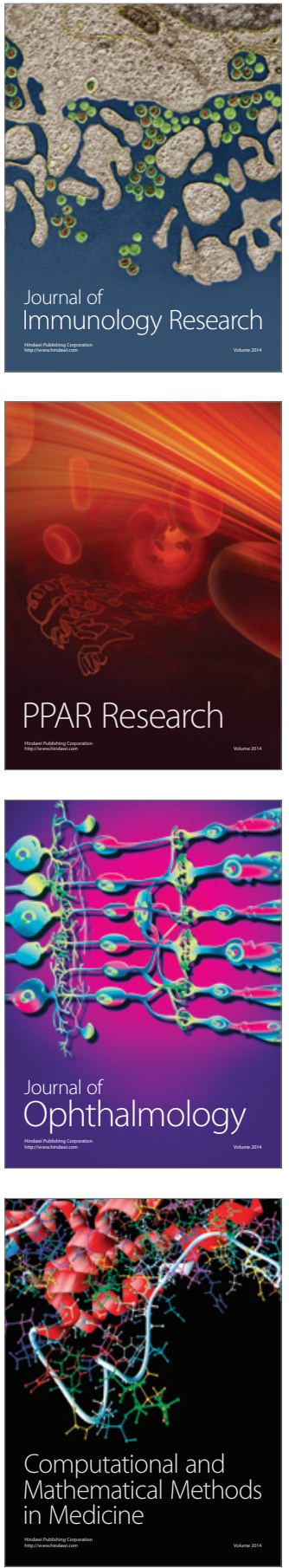

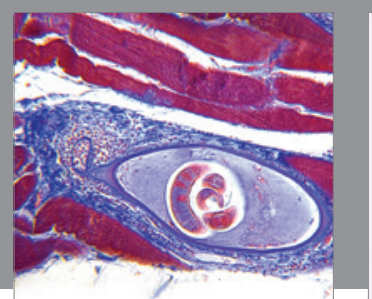

Gastroenterology Research and Practice

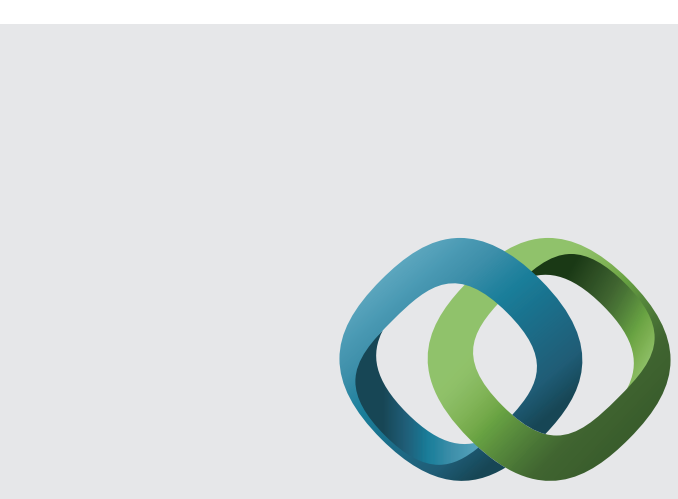

\section{Hindawi}

Submit your manuscripts at

http://www.hindawi.com
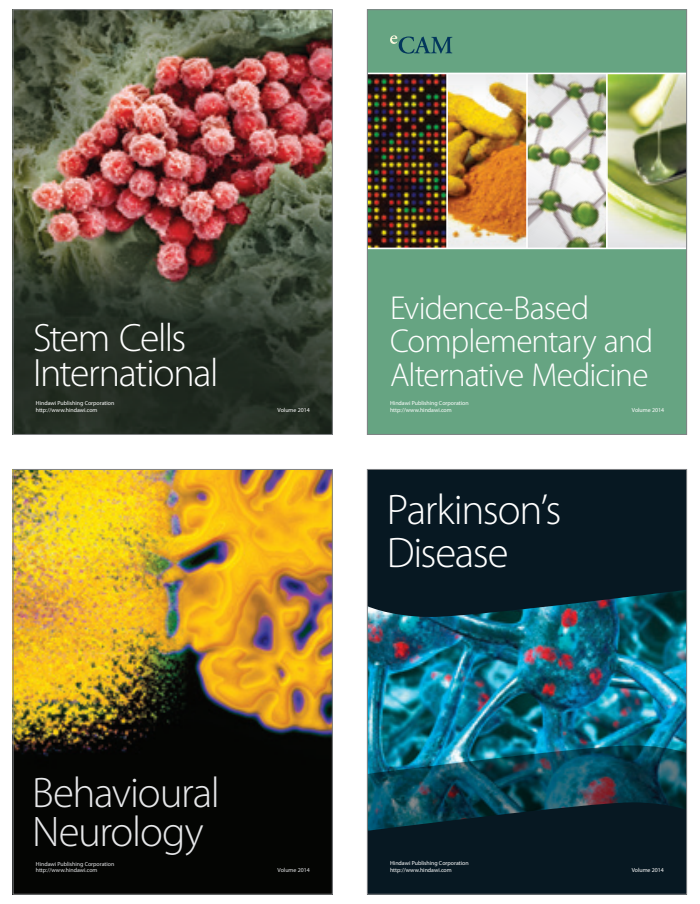
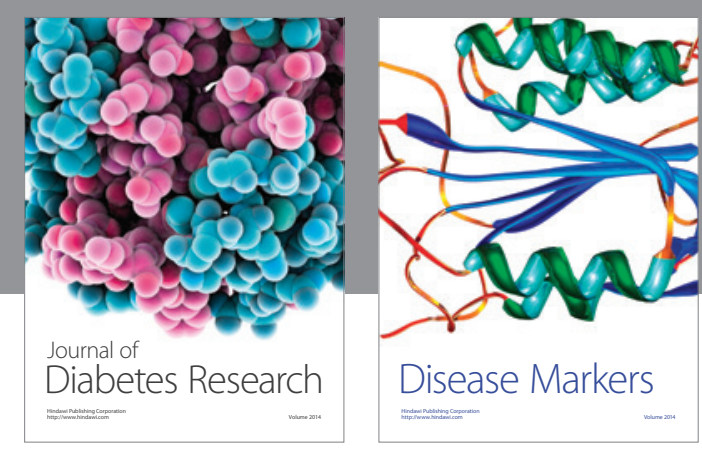

Disease Markers
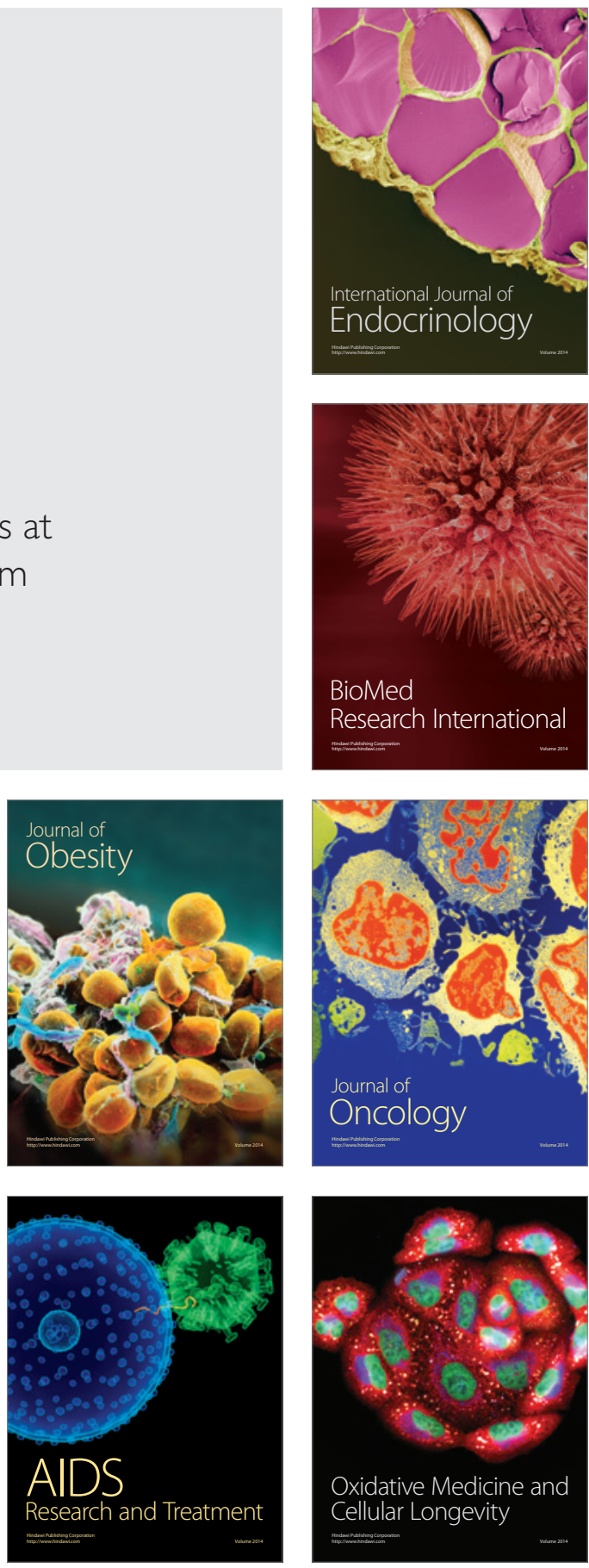